\title{
Role of Water Structure-Making/Breaking Ions in the Cationic Flotation of Kaolinite: Implications for Iron Ore Processing
}

\author{
Mark Ma*, Warren J. Bruckard, David McCallum \\ CSIRO Process Science and Engineering, Box 312, Clayton, Victoria, 3168, Australia
}

\begin{abstract}
Australia is the largest exporter of iron ore in the world. The high Al content in Australian hematite/goethite ores is detrimental to blast furnace and sinter plant operations. Of the Al containing minerals in iron ore, kaolinite is a common gangue mineral frequently found in iron ore deposits. In iron ore flotation pulp, various ions exist and may interfere with the flotation performance when their concentration is high enough. In this work, the role of a water structure-making ion, i.e. $\mathrm{Na}^{+}$, and a water structure-breaking ion, i.e. $\mathrm{K}^{+}$, in the flotation of kaolinite under reverse cationic flotation conditions, the most widely used flotation route of iron ore in the world, was studied in a series of laboratory batch flotation tests. It was found that $\mathrm{K}^{+}$, a water structure breaker, can better reduce the zeta potential of kaolinite and thus causes higher flotation recovery of the clay mineral, in comparison to $\mathrm{Na}^{+}$, a water structure maker. The different effects of the alkali metal cations on kaolinite flotation are attributed to the different aggregation degree of kaolinite particles in the presence of these cations.
\end{abstract}

Keywords Kaolinite, Flotation, Amine, Water Structure Maker, Water Structure Breaker

\section{Introduction}

Australia is the largest exporter of iron ore in the world. A significant problem with the Australian hematite/goethite ores is their high $\mathrm{Al}$ content. The high $\mathrm{Al}$ content in iron ore results in a highly viscous slag and high coke rate and thus is detrimental to blast furnace and sinter plant operations. Of the $\mathrm{Al}$ containing minerals in iron ore, kaolinite is a common gangue mineral frequently found in iron ore deposits [1-9].

The water structure-breaking or structure-making capabilities of the ions in iron ore flotation pulp are usually ignored when discussing the performance of iron ore flotation. The concept of "water structure breakers" and "water structure makers" was first introduced by Gurney, and Frank and Wen who postulated that each ion is surrounded by three distinct regions of water structure[10,11]. In the first layer, water molecules are tightly bound to the ion. The second region extends farther away from the ion and is referred to as the region of structure breaking. Only at larger distances, where the ionic field is weak, water molecules form the "normal" ice-like structure.

Small (in terms of crystallographic radii), strongly

* Corresponding author:

mark.ma@csiro.au (Mark Ma)

Published online at http://journal.sapub.org/

Copyright (C) 2012 Scientific \& Academic Publishing. All Rights Reserved hydrated ions reinforce the "normal" structure of water and the region of structure breaking disappears. In contrast, large less-hydrated ions disturb the ice-like structure and generate an extensive region of structure breaking. Structure-breaking ions are also referred to as chaotropes whereas structure makers are known as kosmotropes[11].

In the author's previous work[7], the flotation mechanism of kaolinite was found to be related to its unique face-edge structure. The presence of $\mathrm{Na}^{+}$in the flotation pulp drastically interferes with the cationic flotation of kaolinite. In this work, the role of $\mathrm{Na}^{+}$, a water structure maker, and $\mathrm{K}^{+}$, a water structure breaker, in the cationic flotation of kaolinite, which has never been studied in the literature, was studied.

\section{Experimental}

\subsection{Materials}

The kaolinite sample (Georgia, USA) was provided by Ward's Natural Science Establishment. Quantitative X-ray diffraction analysis shows that the sample contains $93 \%$ kaolinite and $7 \%$ illite. The average particle size of the sample was determined to be $4.2 \mu \mathrm{m}$ using a Malvern Mastersizer 2000. The sample was blended and riffled into $100 \mathrm{~g}$ charges for flotation tests.

Flotigam EDA 3 (Clariant), an ether monoamine, and Flotigam 2835-2L (Clariant), an ether diamine, were used as 
collectors for kaolinite. Sodium chloride, hydrochloric acid and sodium hydroxide were ACS-certified chemicals from Ajax Finechem.

\subsection{Methods}

The zeta potential of kaolinite particles was studied with the use of a Zetacompact Z8000 model (CAD Instrumentation, France). An electric field of $80 \mathrm{~V} / \mathrm{cm}$ was applied on kaolinite suspensions. Results were based on an automated video analysis of particles. Zeta potentials were calculated from electrophoretic mobility using the Smoluchowski equation.

The batch scale flotation tests were conducted in a modified $1 \mathrm{~L}$ laboratory stainless steel Denver cell in which the impeller was fitted with a variable speed drive and was driven from below, to allow the whole surface of the froth to be scraped with a paddle at a constant depth and rate[12]. For both conditioning and flotation the impeller speed was maintained at $900 \mathrm{rpm}$. Air was delivered to the cell at 4.8 $\mathrm{L} / \mathrm{min}$. Before flotation, $100 \mathrm{~g}$ kaolinite was added to the cell and first conditioned for $5 \mathrm{~min}$ while adjusting $\mathrm{pH}$, and then conditioned with the added collectors for a further $2 \mathrm{~min}$. Froth was scraped once every $5 \mathrm{sec}$. Distilled water was used in all the flotation tests.

\section{Results and Discussion}

As Figure 1 demonstrates, the magnitude of the zeta potential of kaolinite particles over the entire studied $\mathrm{pH}$ range from 5 to 10 follows the Hofmeister series. The zeta potentials are more negative in the presence of sodium cations and less negative in the presence of potassium cations.

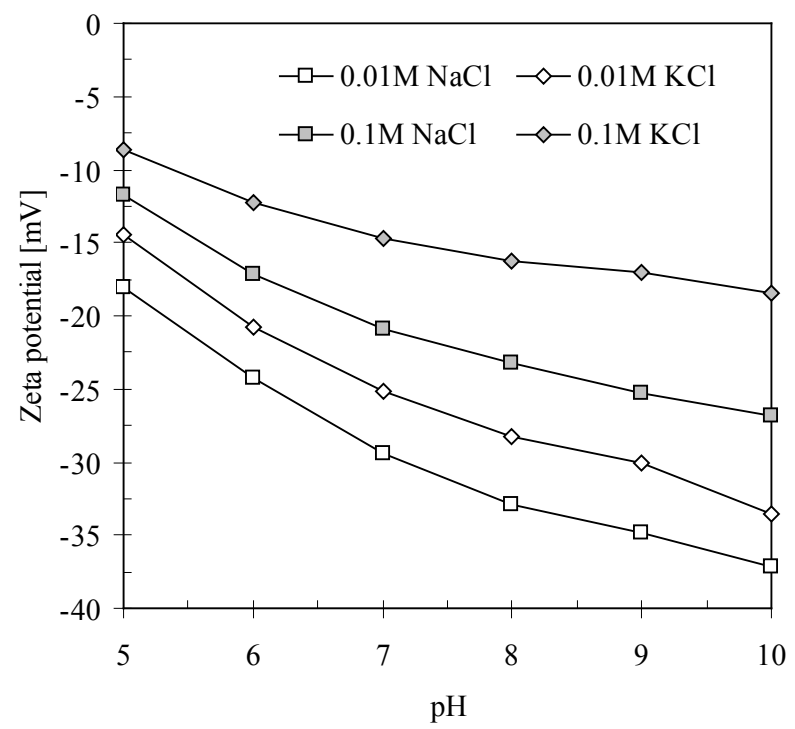

Figure 1. Zeta potential of kaolinite in the presence of $\mathrm{NaCl}$ and $\mathrm{KCl}$ in the $\mathrm{pH}$ range from 5 to 10

The results indicate that potassium cations adsorb at the kaolinite-solution interface in higher quantities than sodium cations, and thus more efficiently screen the negative surface charges around the kaolinite particles, which decreases the magnitude of the measured zeta potentials. This phenomenon is similar to that observed on quartz particles in the presence of sodium and potassium cations in the author's earlier work $[13,14]$.

Similar to the surfaces of quartz, kaolinite surfaces are also highly hydrophilic, coated with a layer of immobilized interfacial water molecules[15]. Such immobilized interfacial water molecules are oriented under the electrical field in the electrical double layer of kaolinite. For the metal cations to adsorb onto such mineral surfaces, the hydration water molecules around the metal cations must be at least partially removed for the metal cations to fit into the interfacial water structure[16].

As a water structure maker, the hydration energy of sodium cations is higher than that of potassium cations, which is a water structure breaker. Therefore, the hydrated water molecules around potassium cations can be removed more easily which facilitates the adsorption of potassium cations onto the surfaces of kaolinite. Accordingly, potassium cations can more efficiently reduce the zeta potential of kaolinite particles, in comparison to sodium cations, as shown in Figure 1.

Figure 2 presents the flotation recovery of kaolinite in the presence of sodium and potassium cations, using two different cationic collectors, i.e. ether monoamine and ether diamine, at $\mathrm{pH} 10$. Reverse cationic flotation is typically conducted in the $\mathrm{pH}$ range from 10 to 10.5 .

In distilled water, ether diamine does not induce any flotation of kaolinite, while ether monoamine results in $67.4 \%$ flotation recovery of kaolinite under the same conditions. The presence of sodium and potassium cations both increase the flotation recovery of kaolinite significantly, with higher flotation recovery produced in the presence of potassium cations.

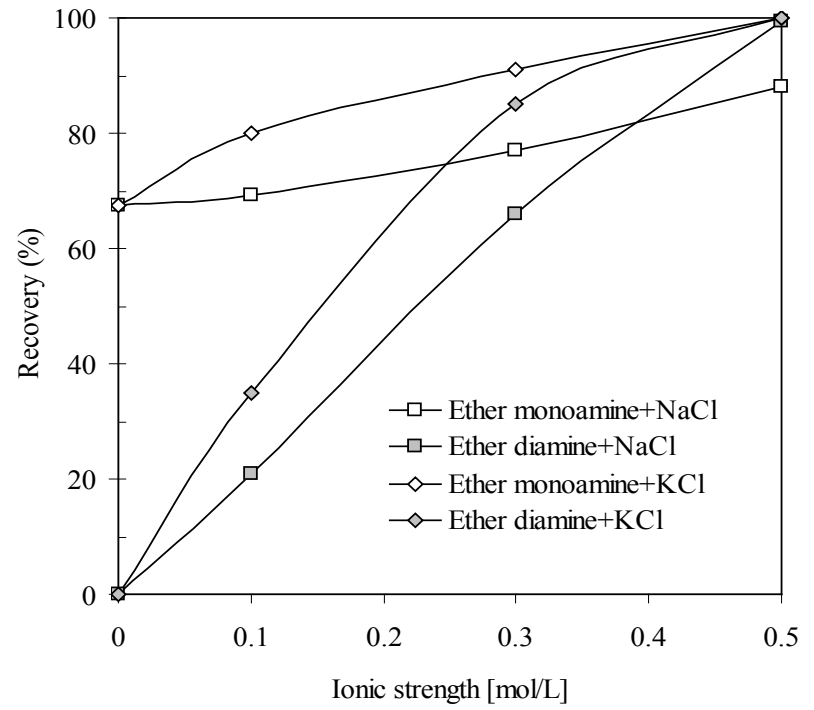

Figure 2. The flotation recovery of kaolinite in the presence of $\mathrm{NaCl}$ and $\mathrm{KCl}$, using $400 \mathrm{~g} / \mathrm{t}$ ether monoamine and ether diamine as collectors $(\mathrm{pH}=10)$.

Figure 3 and 4 illustrate the effect of sodium and potassium cations on the flotation recovery of kaolinite over the 
$\mathrm{pH}$ range from 5 to 10 , using ether monoamine and ether diamine as the collector of kaolinite. Over the entire studied $\mathrm{pH}$ range, both sodium and potassium cations increase the flotation recovery of kaolinite, while potassium cations demonstrate stronger effects than sodium cations.

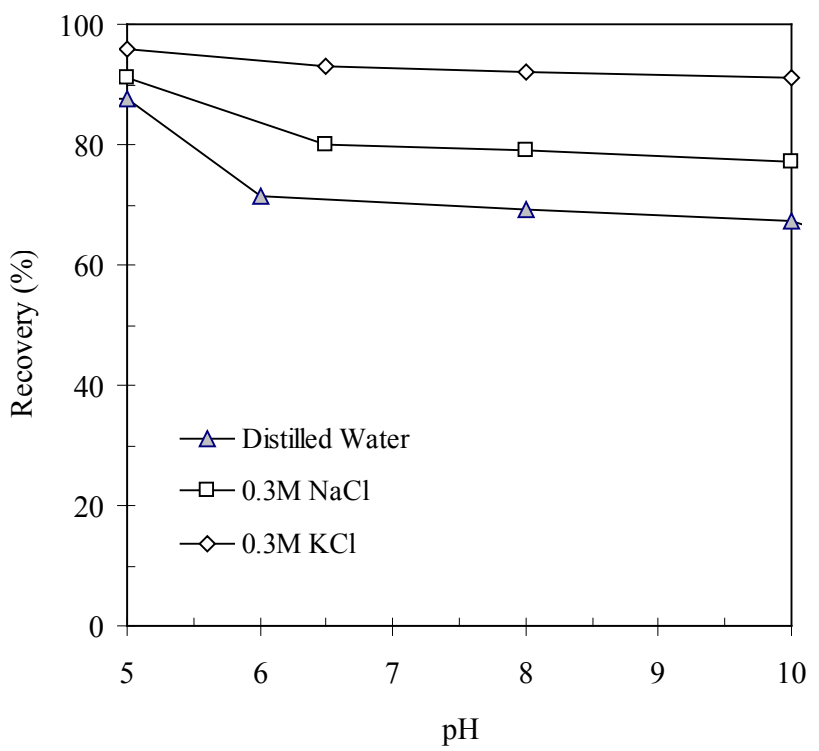

Figure 3. Flotation recovery of kaolinite as a function of $\mathrm{pH}$ in distilled water, $0.3 \mathrm{M} \mathrm{NaCl}$ and $0.3 \mathrm{M} \mathrm{KCl}$ solutions, using $400 \mathrm{~g} / \mathrm{t}$ ether monoamine as a collector

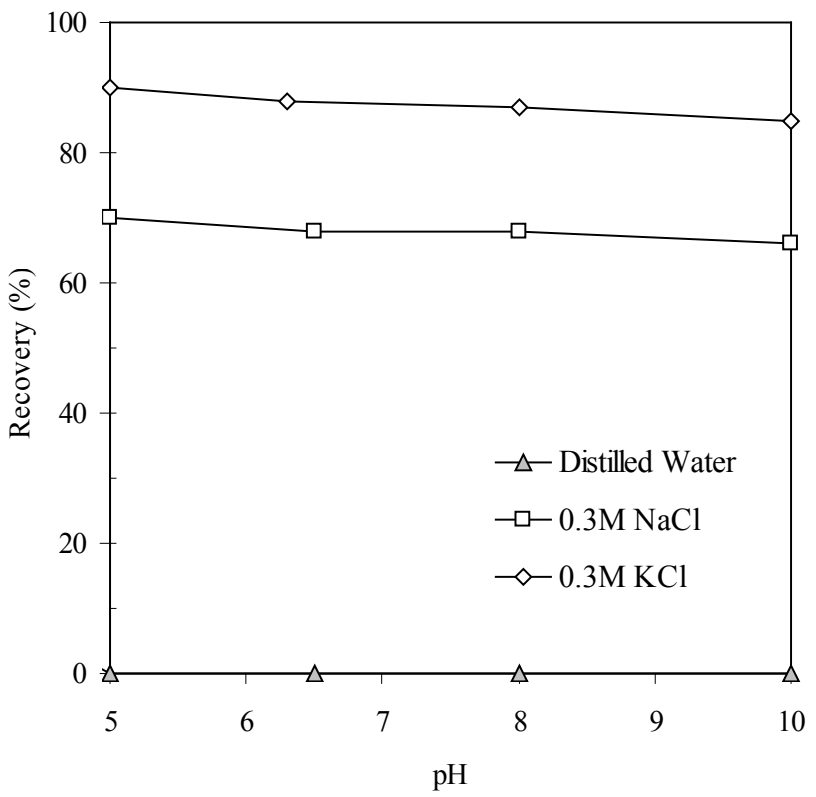

Figure 4. Flotation recovery of kaolinite as a function of $\mathrm{pH}$ in distilled water, $0.3 \mathrm{M} \mathrm{NaCl}$ and $0.3 \mathrm{M} \mathrm{KCl}$ solutions, using $400 \mathrm{~g} / \mathrm{t}$ ether diamine as a collector

Ether monoamine and ether diamine are both used as the collectors of silicate gangue minerals in the iron ore industry. It is known that diamines are stronger collectors for quartz, in comparison to monoamines with comparable chain length [7, 17-21], because of the more acidic $p K a$ values of diamines in comparison to monoamines and the doubly charged amine species of the diamines which promote stronger flo- tation of quartz[21]. However, for the flotation of kaolinite, whose flotation mechanism is different from that of quartz, ether diamine does not induce any flotation recovery of kaolinite particles at all.

Because of the difference in the structure of the silica plane and the alumina plane of kaolinite, the interactions between ether amine and the silica plane of kaolinite is stronger than that between ether amine and the alumina plane [7]. Therefore, amine molecules preferentially adsorb on the silica plane of kaolinite, while leaving the alumina plane unoccupied. The silica planes coated with amine molecules become hydrophobic and further aggregate with each other through hydrophobic forces. Such aggregation exposes the hydrophilic alumina planes towards the liquid phase (Figure 5 , a). Because ether diamine is a strong collector in iron ore flotation, its capability to induce such aggregation is also stronger than ether monoamine[7], which is responsible for the poor flotation in the presence of ether diamine.

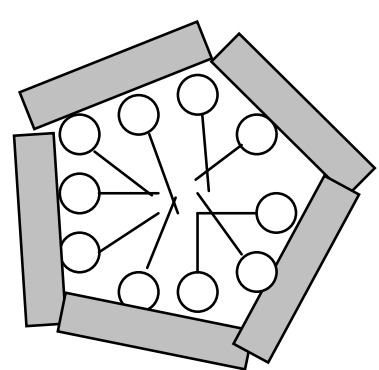

(a)

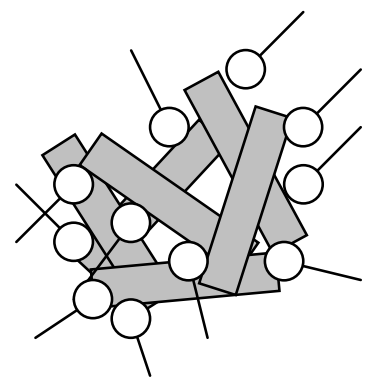

(b)
Figure 5. Schematic description of the kaolinite-amines interactions. (a) Amine adsorption on dispersed kaolinite particles. (b) Amine adsorption on kaolinite particles coagulated by metal cations

The aggregation of kaolinite particles is related to their layered structure[22,23]. When sodium and potassium cations are present in the flotation pulp, these cations cause aggregation of kaolinite particles by reducing the zeta potential of kaolinite particles, as shown in Figure 1. When amine collectors are added to the flotation pulp, they adsorb on the aggregated kaolinite particles in random directions and form a hydrophobic system (Figure 5, b). Therefore, both sodium and potassium cations increase the flotation recovery of kaolinite. Because potassium cations, as water structure breakers, can better reduce the zeta potential of kaolinite, the flotation recovery of kaolinite is higher in the presence of potassium cations in comparison to sodium cations.

\section{Conclusions}

The role of sodium and potassium cations in the flotation of kaolinite was studied using zeta potential measurements and batch scale flotation tests. It was found that both sodium and potassium cations increase the flotation recovery of kaolinite significantly, but the effect of potassium cations is stronger than that of sodium cations. As a water structure breaker, potassium cations can better adsorb onto the sur- 
faces of kaolinite covered interfacial water structure, in comparison to sodium cations, and thus better reduce the zeta potential of kaolinite particles, which in turn causes stronger aggregation of kaolinite particles and higher flotation recovery of the clay mineral.

\section{ACKNOWLEDGEMENTS}

The author would like to thank the Minerals Down Under, CSIRO National Research Flagship for support of this research.

\section{REFERENCES}

[1] M. Ma, 2012. The significance of dosing sequence in the flocculation of hematite. Chem. Eng. Sci. 73, 51-54.

[2] M. Ma, 2011. Enhancement of hematite flocculation in the hematite-starch-(low-molecular-weight) polyacrylic acid system. Ind. Eng. Chem. Res. 50, 11950-11953.

[3] M. Ma, 2011. The dispersive effect of sodium silicate on kaolinite particles in process water: implications for iron ore processing. Clays Clay Miner. 59, 233-239.

[4] M. Ma, 2011. Effect of a low-molecular-weight polyacrylic acid on the coagulation of kaolinite particles. Int. J. Miner. Process. 99, 17-20.

[5] M. Ma, 2010. Role of hydrolyzable metal cations in starch-kaolinite interactions. Int. J. Miner. Process. 97, 100-103.

[6] M. Ma and W. Bruckard, 2010. Effect of $\mathrm{pH}$ and ionic strength on starch-kaolinite interactions. Int. J. Miner. Process. 94, 111-114.

[7] M. Ma, W.J. Bruckard, and R. Holmes, 2009. Effect of collector, $\mathrm{pH}$ and ionic strength on the cationic flotation of kaolinite. Int. J. Miner. Process. 93, 54-58.

[8] M. Ma, 2011. The dispersion of kaolinite. Proceedings of Iron Ore 2011, AusIMM, Perth, pp. 471-474.

[9] M. Ma, W. Bruckard, and D. McCallum, 2010. Adsorption of starch on koalinite surfaces, XXV International Mineral Processing Congress, Brisbane, Australia.

[10] R.W. Gurney, 1953. Ionic Processes in Solution, McGraw-H ill, New York,
[11] H.S. Frank and W.Y. Wen, 1957. Ion-solvent interactionstructural aspects of ion-solvent interaction in aqueous solutions: a suggested picture of water structure. Discuss. Faraday Soc. 24, 133-140.

[12] P.J. Guy, 1992. The development of laboratory batch flotation equipment and practice at CSIRO Australia, the AusIMM Annual Conference, AusIMM, Melbourne, pp. 75-79.

[13] M. Ma and M. Pawlik, 2005. Effect of alkali metal cations on adsorption of guar gum onto quartz. J. Colloid Interface Sci. 289, 48-55.

[14] M. Ma and M. Pawlik, 2006. Adsorption of guar gum onto quartz from dilute mixed electrolyte solutions. J. Colloid Interface Sci. 298, 609-614.

[15] M. Ma and M. Pawlik, 2007. Role of background ions in guar gum adsorption on oxide minerals and kaolinite. J. Colloid Interface Sci. 313, 440-448.

[16] M. Ma, 2008. Role of solvation energy in starch adsorption on oxide surfaces. Colloid. Surface. A. 320, 36-42.

[17] Bleier, A., Goddard, E.D., and Kulkarni, R.D., 1976. The structural effects of amine collectors on the flotation of quartz. In: Fuerstenau, M.C., Flotation, A.M. (Eds.), Gaudin Memorial Volume. AIME, New York, pp. 117-147.

[18] Smith, R.W., 1988. Cationic and amphoteric collectors. In: Somasundaran, P., Moudgil, B. (Eds.), Reagents in Mineral Technology. Marcel Dekker, New York, pp. 219-256.

[19] Smith, R.W., 1989. Structure-function relationships of long chain collectors. In: Sastry, K.V.S., and Fuerstenau, M.C. (Eds.), Challenges inMineral Processing. SME/AIME, Littleton, pp. 87-116.

[20] Smith, R.W. and Scott, J.L., 1990. Mechanisms of dodecylamine flotation of quartz. Miner. Process. Extr. Metall. Rev. 7, 81-94.

[21] Scott, J.L. and Smith, R.W., 1991. Diamine flotation of quartz. Miner. Eng. 4, 141-150.

[22] Missana1, T. and Adell, A., 2000. On the applicability of DLVO theory to the prediction of clay colloids stability. J. Colloid Interface Sci. 230, 150-156.

[23] Rao, F., Ramirez-Acosta, F.J., Sanchez-Leija, R.J., Song, S., and Lopez-Valdivieso, A., 2011. Stability of kaolinite dispersions in the presence of sodium and aluminum ions. App. Clay Sci. 51, 38-42. 